\title{
Hydrospheric nature of global catastrophes
}

\begin{abstract}
With the advent of the XXI century, interest in catastrophism increases in the science. From the catastrophic view more productive to interpret the events of the geological past. The article tries to revive the traditions of neptunizm seemingly finally defeated in the fight against plutonism. The author considers manifestations of giant hydrosphere catastrophes in the later history of the Earth. The attempt is being made to calculate the power of the former megawaves by destructive effects of contemporary tsunami. that are consider as widespread traces of the ancient glacial ages. The formation of boulder-moraine layers and landforms, usually interpreted as evidence of ice ages, are well correlated with the action of megawaves. The giant ripple currents, moraine ridges, eskers and drumlins can form, for example, the tsunami that occurred under the influence of tectonic movements in the Arctic Ocean, or the impact of a celestial body in the ocean. The reinterpretation of their origin in line with the impact-catastrophic model can serve as a new, or rather «well-forgotten old» compass of not only practical, but also scientific and philosophical search. Accordingly, approaches and methods should be strengthened in the diagnosis of «ancient glacial» forms. The purpose of catastrophically fast burial places of a once flourishing life, processes of coalification, petrification and other of global extinctions we have being found in the preservation of oxygen in the atmosphere. Burial and isolation of such biomass allowed new life again to saturate the atmosphere with oxygen. The possibilities of the application of the target paradigm in the annex to the giant extinctions in Earth's history are examined. At last, all that concerns the fundamental genesis lies in the realm of science fiction, or even beyond. There also may be the cause and nature of global catastrophes. What is more important, science is needed for a wider diversification of views. This is the guarantee of its development and interest in it from the outside the public and young people.
\end{abstract}

Keywords: hydrospheric disaster, megatsunami, global extinctions, ice ages
Volume 3 Issue 4 - 2019

Yu N Golubchikov

Leading Researcher of Geographical Faculty of Lomonosov'

Moscow State University, Russia

Correspondence: Yu N Golubchikov, Leading Researcher of Geographical Faculty of Lomonosov' Moscow State University, Russia, Email golubchiko@list.ru

Received: July 30, 2019| Published: August 27, 2019

\section{Introduction}

December 26, 2004year in South East Asia is marked a disaster which caused the formation of the usual fault on the bottom of the Indian Ocean. The vertical displacement of the ocean floor in one place only reached $20 \mathrm{~m}$. It is this movement that caused a tsunami. ${ }^{1}$ But if such movements of the ocean floor devastating tsunamis, then what wave splashes could accompany the discharges and failures of large areas of the ocean floor that occurred in the past to a depth of several hundred meters and even kilometers? And what tsunamis could cause splits on the ocean floor, thousands of kilometers long? The same rift splits, extending along the axis of the Mid-Atlantic and other mid-ocean ridges. On the coasts then, according to the words of NF Zhirov, ${ }^{2}$ «super tsunami» should have arisen, whose wave height when approaching the shores is difficult to calculate. These will no longer be waves, but giant super waves. According to the assumptions of the Vladivostok scientist SA Zimov, ${ }^{3}$ they will reach $220-2200 \mathrm{~m}$ off the coast. Crossing the ocean and repeatedly reflecting off the coast, such waves will cause tremendous destruction throughout the flat land of the Earth. At the approach to the shores of giant megawave would occur flows with speeds of tens, and perhaps hundreds of meters per second? In modern conditions of near-bottom velocities in wave-cut zone can reach only a few meters per second. Speeds of about $5 \mathrm{~m} / \mathrm{s}$ and higher are developed only upon impact wave on the beach. But the destructive capacity flows with velocities of tens to hundreds of meters per second and the water flow in millions of cubic meters per second, we cannot imagine. Nevertheless, this does not mean that such flows could not be.
Simply, they are not observed at present. Their appearance could occur as a result of quite ordinary tectonic disaster, only greater intensity and areal extent. Even Cuvier ${ }^{4}$ believed in time of these events acted qualitatively extraordinary power with a much more powerful energy may be carried out according to other laws than it is today. Modern processes, even if they act millions of years, it is still not enough to build the Alps or the Caucasus. Although it could be the same volcanic eruption or earthquake, act only with infinitely more powerful energy. Modern science does not give grounds to assert that the forces dormant today, could not manifest itself in the past, or properly understood by us in the present.

Giant waves can occur in the fall into the ocean of large space bodies. They appeared at every tide-generating force strengthening, associated with the approach to the Earth of large space objects. In all such cases, there is a powerful tectonic movement, earthquakes, flash turbulence in ocean and lakes, ocean surfaces misalignment levels strongest saturation of atmospheric water vapor and carbon dioxide. Giant megawaves can occur in different ways in the geological past of the Earth.

AN Rudoy ${ }^{5}$ calculated the flow rates of the flood streams formed during breakthroughs of glacial lakes according to the parameters of the ridges of the grandiose paleoflows of Altai and their granulometric composition. The drainage channels are made up of hundreds of thousands and millions of cubic meters per second. GS Ananev ${ }^{6}$ noted that at these speeds, where the flow undergoes necking, it starts cavitation phenomenon associated with heavy «cold boiling» and the occurrence of a kind of explosive mixtures of water and water vapor. Also important is the ability to differentiate portable water flow 
of material. If, at gigantic speeds, they all mix together, then with a decrease in the speeds of matter, they fall out in separate fractions. The destructive ability of these powerful streams with speeds of hundreds of meters per second in vast areas, we simply cannot imagine. The erosive ability of water depends on the third degree of the speed of its movement, and the transporting ability - on the sixth degree of this speed. The destructive activity of the giant megawaves was mainly aimed at moving over long distances loose sediments both from the sea to the land side, and from the land to the sea side. How are they reflected in the geological record of rocks?

SA Zimov ${ }^{3}$ argues that the deposition of giant megawaves does not seem to produce anything supernatural. They leave behind the most ordinary rhythmic layers of rocks. Geologists often encounter such repeated sediments across the section and treat them as reflecting multiple offensives (transgressions) and retreats (regressions) of the sea associated with tectonic movements or climate fluctuations. In both cases, these processes are regarded as relatively smooth and slow, going on for many thousands of years, under the influence of repeated tectonic subsidence and uplifts of the earth's surface or warming and cooling. In fact, they may turn out to be traces of catastrophically huge ebbs and flows, repeated throughout only a few days or months, or even hours. We can observe their model when we throw a stone into a puddle.

SA Zimov is trying to reproduce this process. When megawaves arise, the flows of catastrophic tides quickly become saturated with sediments from eroded rocks. Turbid seawater deposits powerful sediments on land. They often do not carry any remnants of the fauna and are mistaken for traces of the «slow» advance and retreat of the sea or hypothetical glaciers. With a decrease in flow rates, both on land and at sea, large sediments fall first. At first these are boulders. Then pebbles, gravel and sand are deposited. Smaller sediments - silt, clay, silt settle in a more relaxed atmosphere in the form of extensive cloak. With repeated exposure to megawaves formed, for example, as a result of the impact of the asteroid connects SA Zymov formation of coal-bearing strata. Almost all carbon fibers are enclosed in layers of sandstone or shale. On top of these layers are often covered with limestone, and below are underlain by conglomerate rock catastrophically rapid formation and accumulation. Some coal and limestone layers as thin as a few centimeters extend over many thousands of square kilometers. At the same above and below the underlying layers devoid of any fossil coal residues. This cycle is usually repeated. The major coal basins there are tens of cyclites. Seams of coal, belonging to various age strata, is run through vertical tree trunks. There was even a term polistrat fossils. They indicate that coal layers formed very quickly, otherwise the tops of the trees would have time to decompose.

Repeated wash megawaves rich coastal vegetation, densely packed its coves and bays. Then the layer thickness sunken vegetation crown eroded by land unconsolidated sediments. Crop residues will be overlapped by exposure to oxygen. Then another megawave cover the top of new mass of plant residues. ${ }^{3}$ Coal formation in this hypothesis goes catastrophically fast. This contradicts the geological sciences slow its accumulation as a result of repeated transgressions and regressions of shallow seas. In fact, no one knows how much time is needed for the formation of a reservoir. Plast any power and can accumulate over millions of years, and in seconds during various disasters.

AV Lalomov ${ }^{7}$ studied the Triassic-Jurassic conglomerates, sandstones and shales (flysch) in the Crimean Mountains. The researcher set out to reconstruct the conditions of accumulation paleogidrodinamc this column. They were comparable to modern catastrophic mudflows. Only developed paleoflow not in a narrow mountain valley with steep slope bed, and in the vast territory with a predominantly flat terrain. These strata of conglomerates and sandstones are not unique. They are typical for the whole of the Alpine-Himalayan fold belt, and for many other fold belts. For them, the very characteristic curved layers of rocks of considerable thickness, without any trace of the split, indicating that once the rocks are soft and flexible state. They were saturated with moisture and at the time of folding has not yet had time to harden. In the past, these waves can occur quite often. Bowels of the earth had not yet lost its energy. Even written history suggests a much greater intensity and frequency of earthquakes than today. Prominent geophysicist MD Rukin $^{8}$ conveys to us historical accounts of ancient Mediterranean that almost every year, on average, they occur within one catastrophic earthquake. Such, for example, numerous earthquakes in Greece during the Peloponnesian War (431-404 BC.), Described their contemporary Thucydides. In Rome, only one year of the Punic Wars (217g. BC) between Rome and Carthage 57 earthquakes occurred. The ancient city of Antioch (now a resort Antalya) was destroyed by earthquakes 9times. Troy, too, as it turned out, was destroyed by an earthquake. Today these calamities there are quite rare. M.D. Rukin gives information about medieval earthquakes in the Russian Plain related to today certainly seismically stable areas.

The Bible mentions frequent earthquakes in Palestine, and we must treat the Bible as Schliemann to Homer. «Why do scholars who are inclined to believe every fragment of the annals, even hundreds of times rewritten, every clay tablet and birch bark, even believe the old newspaper and sometimes refuse to accept biblical texts as a source of information? Why are they looking for other evidence in which they believe that all the wisdom of mankind is gathered? Truly, they were looking for mittens, and they were looking for it in the bosom, «- draws attention ID Zorin. ${ }^{9}$ The Ashgabat earthquake on the night of October 5-6, 1948 was the most significant in the USSR in the number of victims. As a result, 110 thousand people died. At the epicenter there were 10points, but 8-9 was enough to destroy the whole of Ashgabat. But if the epicenter of the earthquake would fall on uninhabited or sparsely populated territories, which are many not far from Ashgabat, then information about it would be stored in dusty archival reports. Nobody would have known about him, especially since the information about earthquakes in the USSR was classified. The number of victims of the Ashgabat earthquake was first reported in the early 1990s. True, even in the lectures of Professor GP Gorshkov in the first year of the Faculty of Geography of Moscow State University, I heard in 1971 that although we have all the disasters, where more than four people died, state secrets, he takes the liberty of informing us that the number of victims of the Ashgabat earthquake is 72 thousand people. The figure then looked stunning.

But Ashgabat earthquake was not the most powerful in the USSR. Kuznetsk earthquake in 1898 was 11 points. The strength of earthquakes in the Baikal region more than once reached 10 points. This example earthquake occurred here in 1960. But it took it in a completely uninhabited area at the time. Better known case of the 9-magnitude earthquake in 1861 that destroyed the Buryat village and its inhabitants. Then, in the delta of the Selenga Tsagan steppe area of about 260 square meters. $\mathrm{km}$ sank to a depth of $8 \mathrm{~m}$ below the water lake, bay forming failure. And how many such cases are not included in the annals of any chronicles, and how many of them occurred in the bottom of the seas and oceans? 


\section{The revival of neptunism}

Studying from satellite images the parallel arches of moraine ridges on the Russian and West Siberian plains, M.G. Groswald in the direction of their radii revealed the places where these grandiose movements began..$^{10}$ It turned out that all their starting points lie in the Arctic Ocean, even in its deep-sea parts. M.G. Groswald suggested that the ice sheets that appeared on the continents extended to the shelf of the Arctic seas, at the bottom of which grew a giant ice ridge 1700$3000 \mathrm{~m}$ high above sea level (Figure 1).

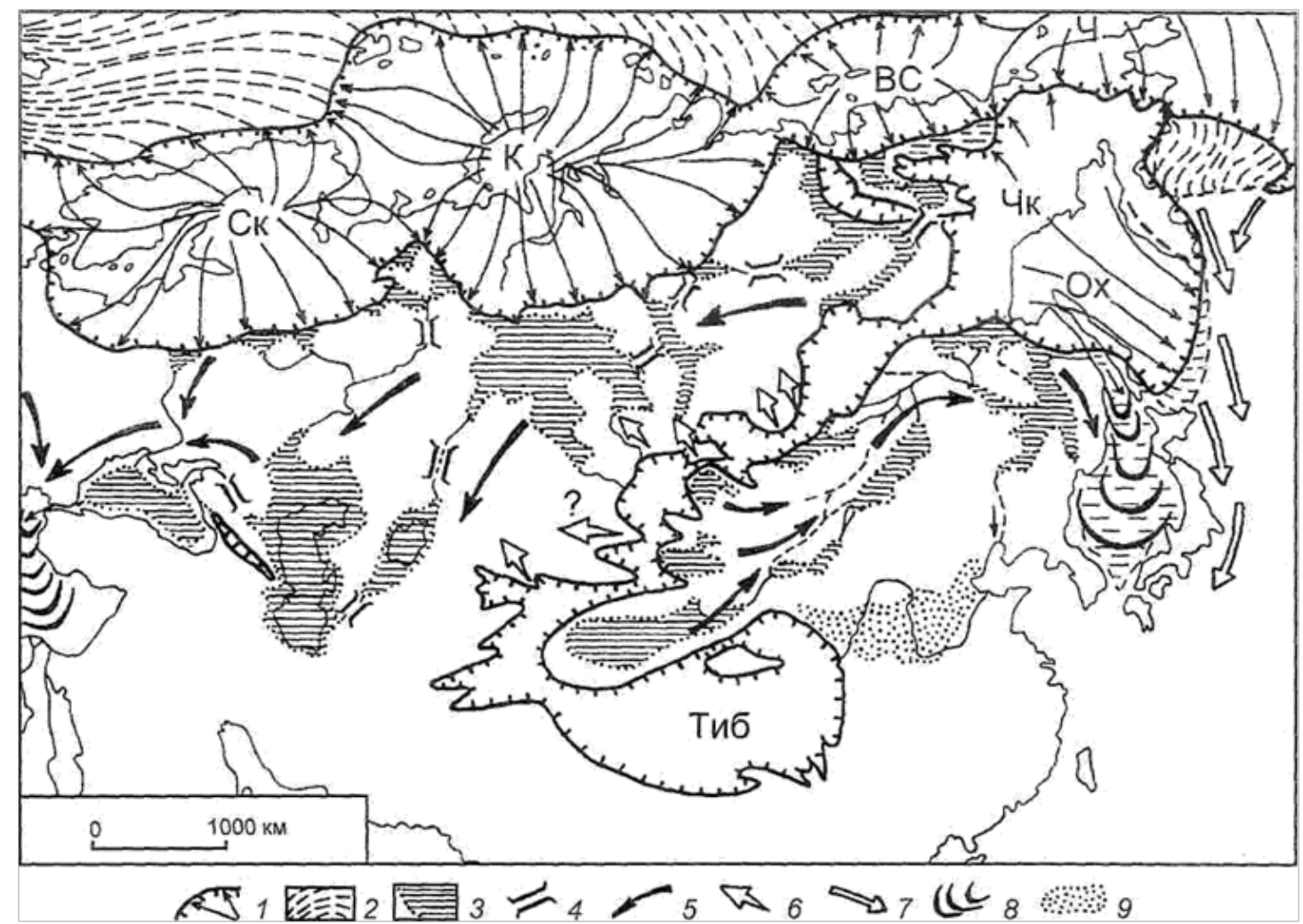

Figure I For reconstructed state of the last glaciation in Eurasia about 20thousand years ago. ${ }^{10}$

I, ice sheets and hot plains; 2 , floating ice shelves; 3 , lakes; 4 , channels of melt water runoff; 5 , the direction of flow; 6 , drained shelves; 7 , free of glaciers ocean; 8 , Sea with tires of melt water; 9 , are the areas of accumulation Chinese loess; Number of lakes, their levels in $m$ altitude.

Icecaps and complexes: CK, Scandinavian; K, Kars; BC, East Siberian; B, Bering (Chukotka center); Chk, Cherskii-Kolyma; Oh, Okhotsk;Tib, Tibetan.

It had the idea of the existence of giant pan-Arctic Eurasian and North American rivers. Along the southern edges of the pan-Arctic ice sheet occurred giant glacier-dammed lake-sea. At some stage, they overflowed and giant short-term water flows (megaflads) regularly discharged to the south with a periodicity of about once per century. Their waters have formed a relief of Western Siberia, Kazakhstan, the Northern Caspian and the Kuma-Manych Depression, in particular, Baer knolls, hollow-ridge and crest relief, «the ancient trough sink». ${ }^{10}$

It is necessary to change the paradigm and does not bind the formation of landforms that are attributable to the ancient glacial or the dumping of glacial waters, like many of the problems of their genesis will be highlighted in a completely new, unexpected light. In recent years, there were many critical reviews glacial paradigm. ${ }^{11-15}$

GU Lindberg ${ }^{16}$ proves that the Quaternary history has seen rapid sea level rise more than once reaching a height of $1000-2000 \mathrm{~m}$. According to Friedrich Ratzel's calculations, the volume of the world's oceans is 13 times the volume of land rising above its level. To absorb all of the Earth's land, the ocean needs to increase its volume by only $7.7 \%$. If the ocean level drops by 1000 meters, then the land surface will increase by only $30 \%$. And if the ocean rises by the same 1000 meters, then the land surface will immediately decline by $80 \%$.
If it were not for the action of tectonic forces, then over 14million years the land would be leveled to sea level. If the Earth were an even sphere without mountains and continents, then the oceans would flood it with an even layer with a depth of 3980 meters. ${ }^{17}$

Modern geological science, which rejected the notion of Neptunism, neglects the serious control of the earth's land by eustatic and deformational fluctuations in sea level. ${ }^{16,18}$ The victory of the plutonists, considering the heat of the earth's interior not as a destructive force, but as a factor of creation, served the formation of modern geological science. This gave rise to Soviet geologists VV Tikhomirov and V.E. Khain to conclude in 1956: «In the struggle of volcanism with reactionary Neptunism, advanced evolutionism with backward catastrophism, geology has finally strengthened as a science about the development of the Earth». ${ }^{19}$

Of the great Russian scholars, VI Vernadsky was the closest to the ideas of Neptunism. A connoisseur of his work RK Balandin writes: «Vernadsky gave obvious sympathies to the external forces of the Earth - living matter, natural waters - and was, one might say, predominantly neptunist». VI Vernadsky himself writes about Neptunists with obvious sympathy: «The Goethe-Neptunist denied the importance of the planet's internal forces for the processes 
observed in geomorphology and in the biosphere in general, attaching primary importance to water, and sought explanation for chemical phenomena in volcanic processes. In essence, here too, the science of our time is closer to Goethe than the prevailing notions of its time and even of the entire $19^{\text {th }}$ century. If we include the phenomena of radioactivity unknown to Goethe, then the ideas of our time about the geological processes of the Earth will be closer to the ideas of Goethe than to the views of plutonist geologists who won in his era. For both volcanic phenomena and mountain-building processes turn out to be manifestations of the earth's crust, and not the interior of the planet. Life, as Goethe thought, plays a huge role in these processes». ${ }^{20}$

RK Balandin argues: «Are there any new facts that refute Vernadsky's opinion about the inertness of about nine-tenths of the planet's volume, starting from depths exceeding eight hundred - a thousand meters? There are no such facts. Seismic activity attenuates to these depths (and it is believed to indicate the movement of deep matter); foci of volcanoes are located even higher. Suppose we are not well known for some of the processes occurring in the Earth's crust. But the deep bowels and we all know almost nothing. Does it make sense to explain what is known bad, what you do not know? ... So Vernadsky believed. In our time, there is no, repeat, no facts, contrary to his views that, ${ }^{21}$ From the time when he wrote these lines, there was a more empirical observations, indicating the water, as the main creative force of the earth's surface. Cartographically set tree structure combinations topography, soil and vegetation, drainage system and the distribution of rocks as their common streaming pattern. ${ }^{22}$

Geology could be defined as the science of destruction and death All sedimentary rocks are the remains of one or another of the former life or veils her burial. Any genesis rock was supposed to destroy the life if they were not formed on a lifeless planet. Look at the geological map and imagine the size of all the destruction and burial. The rocks are formed and these days, but not in the gigantic scale that, in the giant destructive catastrophes.

\section{Global extinctions in the conservation of atmospheric oxygen}

If we keep to the empirically observed facts, the huge deposits of coal, oil and carbonates (limestone, chalk, dolomites, marls) found in ancient earth strata, in particular thick strata of carbonaceous-graphite schists, ferruginous-siliceous Jespilites and stromatolite carbonates of the early Archean, are obvious evidence that the amount of living matter could only decline from that gigantic abundance to our time. V.I. Vernadsky wrote that the earth's crust «captures within a few tens of kilometers a series of geological shells that were once on the surface of the Earth biospheres. This is the biosphere, stratisphere, metamorphic (upper and lower) shell, granite shell. The origin of all of them from the biosphere becomes clear to us only now. These are former biospheres». ${ }^{23}$ So, before us everywhere in granite gneiss there are traces of the former melted biospheres. Granite formations are not found on other planets. Apparently, they are the prerogative of terrestrial biospheres. Will not only such traces remain from our biosphere?

According to VI Vernadsky, ${ }^{23}$ the amount of living matter throughout the history of the biosphere is constant and exists within very narrow fluctuations. Therefore, the constant is the amount of oxygen. This is evidenced by the constancy of the chemical appearance of the earth's crust during the entire geological time and the constant «chemical nature of that grandiose phenomenon in which the chemical action of life is expressed in the biosphere, and which we call the weathering crust» [1965, p. 288]. Cyanobacteria, which left powerful deposits of stromatolite carbonates, could supply free oxygen in Archean. The high oxygen content in the atmosphere of the Early Proterozoic is evidenced by the widespread occurrence of quartz jaspilites, which are an alternation of thin layers composed of hematite $\left(\underline{\mathrm{Fe}}_{2} \underline{\mathrm{O}}_{3}\right)$ and quartz.

What is the purpose of catastrophically fast burial places of a once flourishing life, processes of coalification, petrification? Vernadsky ${ }^{24}$ noted that the amount of carbon contained in combustible minerals and limestone rocks approximately corresponds to the amount of free oxygen in the atmosphere. Coal consists of pure carbon, there is no oxygen in coal, all the oxygen that could combine with coal remained in the atmosphere. «If carbon had not dropped out of the life cycle in the form of hydrocarbons, coals, bitumen, graphites or in the form of calcium carbonates, free oxygen would not have existed at all, so there would have been, therefore, thousands of the most important chemical reactions of the biosphere associated with it»Vernadsky, ${ }^{24}$ Laboratory experiments, which resulted from a conventional timber in less than a month it turns anthracite, show that the formation of coal need not millions of years old, and just a high temperature and pressure in the absence of oxygen. In other words, we need a disaster. Apparently it is necessary for the formation of almost all of mineral deposits.

It can be assumed that the accumulation of hydrocarbon deposits is catastrophically fast. All organic residues easily decompose when oxygen is accessed, and compounds such as oil decompose spontaneously and fairly quickly. This can be observed at any refinery. So hydrocarbon deposits are also buried quite quickly, reliably and very densely. This is not to mention the easily volatile natural gas. Numerous examples of very fast oil production are also accumulated in laboratory conditions. Facts are also accumulating about the rapid accumulation of oil and gas and the replenishment of used oil fields by them over 30-50years. ${ }^{25}$ But nobody has succeeded in reproducing the process of petrification of multicellular organisms. All living beings who have died today are decomposed and do not have time to turn into stone. Microbes, worms, insects do not leave any time for any petrification. Meanwhile, most of the fossils are represented by marine invertebrates without solid skeletal forms (starfish, jellyfish, brachopods and mollusks), which usually do not differ from modern forms. Nowadays, they decay especially quickly. The remains of petrified trees are found almost everywhere. «Stone forests» are known, whole cemeteries of fossilized dinosaurs are found. In order for all such forms to remain fossilized, it is necessary to allow their sudden burial while still alive in the thickness of the sediment. This stratum was to immediately and forever reliably block buried organisms from contact with oxygen and aerobic microbes.

The fossil record is sufficiently tracked how each major extinction of organisms is preceded by a large-scale increase in biodiversity and obviously biomass. By some estimates, the largest and Perm Cretaceous extinctions just preceded by the fall in oxygen levels in the air and sea water. ${ }^{26}$ "If plants and animals as a result of some events will be bricked up or covered with sediments, the atmosphere gets extra oxygen. Perhaps due to this process the free oxygen has been accumulated in the atmosphere. ${ }^{27}$ This could upset the delicate balance of the biosphere oxygen, the amount of oxygen could begin to decline. Abundant biomass, marked the beginning of a huge carbon deposits, most likely, at some stage, not so much now produces oxygen as it absorbs the processes of decay. But, as noted by J. Lovelock:. «Any species that adversely affect the environment, make it less suitable for offspring will eventually expelled as well as weaker evolutionarily unadapted species». ${ }^{28} \mathrm{~A}$ change in the oxygen content by some percent makes the existence of technocivilization impossible. At an oxygen concentration of $25 \%$, everything that can burn out will burn, even 
in heavy rain. Combustible minerals will also burn out - the basis of the technological prosperity of mankind. Conversely, at oxygen concentrations below $15 \%$, any combustion of wood, coal, and other organics will become impossible. ${ }^{29}$ This fact alone would not endow humanity with the powerful energy of fire.

Now the accumulation of huge volumes of biomass is prevented by repeated fires from time to time. But they are possible only with certain oxygen content in the atmosphere. Be it a few percent less and no ignition processes will become impossible. To prevent the accumulation of supervolumes of phytomass, only the burial path will remain. The deposits of coal, hydrocarbons and carbonate proved also conserved enormous reserves of carbon dioxide. Without the preservation of the Earth could comprehend the fate of Venus. Giant burial of organic remains ominously warned against violations of the fragile chemical composition of the Earth's atmosphere. Extinction lush tropical life threatening warns against violations of the fragile balance of oxygen. Apparently, because the anthropic principle is connected with the paleontological extinctions in Earth's history. As a result of such a connection to man and were given oxygen and deposits of fossil fuels. For goods and exaltation of man spread magnificent forests, accumulated deposits of coal and hydrocarbons thick strata of sedimentary rocks. A myriad of invertebrates had to die and cram their strata fossils to the ground was covered with fertile soil.

\section{The death of the Pleistocene megafauna in the formation of mankind}

Modern processes do not give examples of the preservation of carcasses of organisms in a frozen state with soft tissues, as found in the frozen loess strata of Siberia and Alaska. Now, from the mammoth megacomplex that settled in the late Pleistocene (Paleolithic), a large part of Northern Eurasia and North America, giant cemeteries have been preserved. They consist not only of mammoths. In the extracontinental climate of the «mammoth» steppe, polar bears side by side with mastodons, hippos with arctic foxes. Many inhabitants were gigantic in size. They die out at the turn of the Late Pleistocene and the modern Holocene, about 12thousand years ago.

«Long summer finally passed. Huge four-mastodons, elephants, tigers, lions, hyenas, bears, the remains of which are found even in Europe, starting from the southern capes of it up to the northern borders of Siberia and Scandinavia, and in the Americas from the southern states to Greenland and Mavlinskiye islands seem to reign at that time strongly throughout the world. But the reign of them ended suddenly, a terrible winter, which lasted for centuries, suddenly appeared on the Earth, it has spread to the places where these tropical animals lived so long and came with such rapidity that the embalmed their bodies under masses of snow and ice, not gave even step process of decomposition " - wrote founder of glacial Agassiz teachings. ${ }^{11}$ Whole herds of animals, apparently dead, slain by evil force, appear to suddenly lower the Earth's temperature over a huge area. She was not preceded by any phenomenon that could warn of impending trouble. Vegetation somehow survived this attack. Unknown facts and extinction at the turn of the Pleistocene and Holocene any mass fodder plant mammoth within the range of their habitat. Many small and quirky animals also escaped. Those that can quickly and easily overcome great heights, found refuge on the mountain peaks. Among them were bighorn sheep, mountain goat, deer, survived, and those that know how to swim (elk, reindeer, horses). Not dead and mammals associated with the sea life (whales, walruses, seals). Among them was a polar bear.
Dead adult musk ox in his skin and weighing one ton freezes in winter in the lower reaches of the Kolyma River in a few months. ${ }^{30}$ His bowels during this time begin to decompose, the process increases dramatically in the summer, when the body's decomposition begins in ten or twenty hours after the death of a large animal. He was immediately start gnawing animals and birds complete the deal insects and worms. Therefore, from the millions of carcasses of large modern animals living in the wild, not in a hundred years it is in most cases even the skeletons.

Consequently, mammoths appeared in the «refrigerator» before the beginning of their decomposition and subsequently preserved in the frozen state. The corpses of some mammoth so well preserved that their meat can have a dog. Solzhenitsyn begins «The Gulag Archipelago» with an example of how starving prisoners ate meat carcasses found their mammoth.

Now these findings are relatively rare, the year the number of found mammoth tusks measured in units. Apparently, many of the remains of mammoths have washed their banks or destroyed, but in the old days on the New Siberian Islands and the plains of northeastern Siberia, they met very often. Because of the enormous reserves of perfectly preserved mammoth tusks entire east coast of the Arctic Ocean in XIX century called «mammoth bank.»

A polar explorer of Northeast Asia FP Wrangel wrote in 1824: «Despite the large number of mammoth bones exported from Siberia annually, there is no noticeable decrease, and in 1821 a Yakut tradesman removed fangs from New Siberia to 500pounds better quality. ${ }^{31}$ That is, one industrialist exported 8 tons of mammoth tusks during the season, but he exported, obviously, not one. More than a hundred mammoth tusks were taken from the mouth of the Yenisei River in 1875 on the Nils Nordenskjold steamer, and all «from the years when the Russians took control of Siberia, more than 20,000 mammoths were found tusks». ${ }^{32}$

Frozen carcasses of mammoths often lie among underground ice deposits. On the corpses numerous traces of injuries and fractures of leg bones were preserved. Undigested fruits, leaves, nuts, cereals were found in their stomachs. In the mouths of animals and between the teeth, even undeveloped remains of herbs were found, some of which were found with seeds. Another famous polar explorer, Baron Toll, concluded that the catastrophe took animals by surprise and occurred in early autumn. ${ }^{33}$

What froze and immediately buried millions of mammoths and other large herbivores? If the glacier, why they could not bear to walk away from his cold breath? If the climate changes, why mammoths survived previous, is believed to be the glacial era of climatic changes?

The mystery of the death of the mammoth megafauna would have to attract the attention of not less than the extinction of the dinosaurs, in relation to the death which causes catastrophic science allowed. Another great Cuvier wrote: «One and the same process, and destroyed them, and froze the country in which they lived. This incident happened suddenly, instantly, without any gradual. ${ }^{4}$ Similarly treated the death of mammoths and the inhabitants of Siberia. Pass in 1692 through Siberia to China, the Russian ambassador Izbrant Ides wrote: «Old Russians living in Siberia believed that the mammoth was such an animal as an elephant, and that it was warmer in Siberia before the flood than now, and many elephants lived here; they drowned during the flood, and then, when the cold came, they froze into the clay of the rivers. ${ }^{34}$ 
Cuvier first to speak of the "glaciation» as the cause of the disaster that suddenly killed the mammoths and other large animals. He noted that the layers of permafrost hold well-preserved plant and animal remains of tropical origin. Similar burial, - concluded Cuvier - can only be associated with the instantaneous drop in temperature. All that other places can be found in the fossil record, there is provided in the form of fresh frozen. Cuvier thus first formulated concept formation permafrost. Often the animals are, alternating layers of ice and layers of peat. All this testifies to the sudden disasters - concluded Cuvier.

The concept of the formation of glaciers is thus basically a biological nature. Cuvier genius consists in the fact that he was the first to formulate the concept of the formation of permafrost, which accounted for instantly-frozen rocks. Their layers are stored wellpreserved plant and animal remains of tropical origin. A similar effect could be achieved only at the instantaneous temperature is lowered.

Paradoxically, modern biologists tying their constructions to the glacial theory as purely geological do not remember its original biological essence. They do not mention Cuvier, as their predecessor, and permafrost experts. In cryolithology and permafrost science, the accumulation of powerful polygonal vein ice (vertical thickness up to $30 \mathrm{~m}$ ), the extinction of mammoths, and the formation of permafrost are considered as three independent sluggish processes. Meanwhile, the mystery of the death of the mammoth megafauna should have attracted attention no less than the extinction of dinosaurs, with respect to the death of which catastrophic causes by science are allowed.

Together with animals, the waters of giant megawaves could not freeze instantly. Now they appear in the form of underground ice deposits. Subsequently, this soil no longer thawed, since the carcasses did not decompose. The carcasses were immediately buried in mud, sand and pebbles, which, in turn, were instantly fettered by permafrost. The spaces that have become empty after the waves have subsided are again covered with herbs, which are then forced out without the influence of mammoths by mosses and lichens.

However, modern science does not think so. For modern science, the formation of frost, the formation of huge cracks in the frozen soil, and the extinction of the mammoth fauna - these are three separate low-intensity process. Some of paleogeographers even attributed the extinction of the mammoth fauna with the melting of the last glaciation and come to a paradoxical conclusion: «mammoths, hairy rhinos, horses and bison were killed and disappeared not by cooling and the climate warming at the end of the last Ice Age». ${ }^{35}$

It is widely believed that the mammoths destroyed primitive hunters. Mammoth bones found in almost all the sites of the Paleolithic. It is assumed that people would arrange the trap dug pits, and with stunning agility driven to herds of mammoths, and along with them and individuals woolly rhinoceros, buffalo, bison, horses, musk oxen, deer, cave bears and lions. But try to drive into a similar trap at least a flock of sheep.

Moreover, no traces of the many human tribes, where the extinction of large animals was of the most widespread, is not found. In more populated Europe human species extinction scales were lower. In Lithuania and Northern Greece bison survived until the nineteenth century, and in the Northeast Asia, along with the mammoth died, almost all large herbivores.

If any global hunt primitive people or climate have always found a region, located in an acceptable survival extinct species climatic range. Muskoxen survived after all. And why were exterminated Arctic elephants, rather than their tropical counterparts?
We do not know why the mammoth died out, but we can imagine how the survivors of the terrible catastrophe left only after people after retreating sea on Everglades. People walk on the new, completely unknown to them the continent, where they began to discover the cemetery of frozen carcasses with supplies meat diet. No longer had to be worn with stones and spears chasing careless relatives. And so they became a little. Surviving create the first parking lot near the reserves of frozen mammoth carcasses. Instead of bone marrow begin to eat real meat. Near them there is a settled way of life, perhaps, at first not very strong, but at least for a few years

Prior to the Late Paleolithic, no reliable remains of human land dwellings were found, moreover, more or less permanent dwellings. The widespread use of caves and grottoes, too, apparently had a predominantly seasonal character. ${ }^{36}$ Then comes the formation of the first group settlements that grew into the first villages. The dwellings of camps that appeared apparently near cemeteries with freshly frozen corpses of large herbivores were examined in detail by IG Pidoplichko. ${ }^{36}$ They were based on the skulls of mammoths, installed in a circle, and a spherical frame of wooden poles and long bones. The frame was overlapped with skins, which were crushed from above by other skeleton bones and stones. Bones from 30 to 40adult mammoths, plus many mammoth skulls, which were used as props, were spent on the construction of one dwelling. Near the dwelling there were sometimes storage pits of mammoth bones. Modern Chukchi yarangs have a similar appearance, built, of course, already without bones, but using poles and stones. In marine hunters of Chukotka and Alaska, similar structures were constructed using whale bones..$^{36,37}$

Over time, they began to thaw frozen strata. Frozen findings began to dwindle. On the written history of mankind have survived only a few finds of mammoths in the frozen state, although there is no doubt that the five hundred or a thousand years ago, these findings have revealed much more.

Mammoths, apparently, were the establishment of Paleolithic culture in the same way as that hydrocarbon deposits are the modern civilization. You can imagine how the survivors after a terrible catastrophe people could only go down to the marshy valleys, open sea and retreating permafrost in the new continent to detect the cemetery of frozen carcasses with supplies meat diet. Near them there were the first parking lot, there is a partial sedentary, may not be particularly strong, but at least for a few years.

As the depletion of stocks in «cold storage» permafrost, a man accustomed to the places of their habitat and the new power structure. He goes to the hunting and fishing. Large predators are almost gone. Compared with the former inhabitants of the «mammoth» steppe person is now surrounded by smaller animals (elk, deer, horse, bull). Some of them could gradually domesticated and kept as a food reserve, as once conquered neighbors.

\section{The principle of purpose}

Acquisitive mind everywhere sees that inanimate matter is serve to alive, and that, in turn, - to human For goods and exaltation of human spread magnificent forests, accumulated deposits of coal and hydrocarbons thick strata of sedimentary rocks. A myriad of invertebrates had to die and cram their strata fossils to the ground were covered with fertile soil.

There is in all this some kind of a lesson. Man «to till the ground from whence he was taken» (. Gen. 3, 23) «It took a lot of processes and upheavals in the earth ... Is not all we owe elements: and their own existence, and all that we possess, and our home of the Earth? - Wisely 
taught Johann Herder. - Not on the floor of his house treading you have not, but walking on the roof of his house, and gave a lot of floods your house its present form Herder. ${ }^{38}$

Entered the land, a man met all conditions for comfortable existence. «The required minimum for his life was carried out in a different form: the power resources of the fruit - as in the Garden of Eden - to mammoths, in the form of abundant self-cleaning fresh water in the form of fuel for fires. The Earth has already accumulated for creative human fantasy many plant and animal species suitable for domestication and breeding, accumulated storage of fossil fuels, metals, salts, building materials, radioactive substances. In case the new owner of the land wants to, for example, to test their effects on themselves «- wrote AD Armand. ${ }^{39}$

And at the same time, we have a danger in this view of becoming that fattened turkey that Lebanese thinker Nassim Taleb masterfully described: «Every day of feeding will strengthen the bird in the belief that there is a general rule in life: every day, friendly representatives of the human race,» taking care of her welfare, «as the politician would say, they pour grain into the feeder. On the eve of Thanksgiving, something unexpected will happen to the turkey. This will entail a revision of beliefs. The situation with a turkey is summarized as follows: the hand that feeds you can subsequently twist your neck. Turkey based its conclusions on observations, as we are recommended to all (in the end, this is considered a scientific method). Her confidence increased as the number of friendly treats increased, and her sense of security also grew - although the day of judgment was inevitably approaching. Oddly enough, the sense of security and risk peaked at the same time! But the problem is much wider; it concerns the nature of empirical knowledge as such. Something functioned in the past, until ... until it suddenly stopped, and what we learned from this past turns out to be insignificant or false at best, and dangerously disorienting at the worst. ${ }^{40}$

The catastrophes in the history of the Earth and man are likely to prevent much more devastating events. Thanks to the turbulent history of disasters, the future never resembles the past and is not fundamentally derived from it. This is the basis of freedom of choice, which grants development in the long run. Indeed, if they could predict the future and prepare for its surprises, they would be more likely not humans, but biorobots («I would know where to fall, I would lay straws»). In a dangerous risk zone, people and society are forced to look for non-trivial exits, and often brilliant meditative solutions. A catastrophe thus becomes a factor in the development of man and his communities. It has become increasingly clear that in order to approach the knowledge does not have to go down and up; does not degrade the system into its component elements, and study it as part of a larger system - in the limit of everything. Again, relevant postulates of Plato about whole prior to its parts and determine their properties. The power of science again appears not in opposition to religion, but to harmonize with it. .11,42 $^{4}$

\section{Acknowledgments}

None.

\section{Conflicts of interest}

The authors declare that there is no conflict of interest.

\section{Funding}

None.

\section{References}

1. Tappin D, McNeill L, Henstock T, et al. The Indian Ocean Tsunami of December $26^{\text {th }}$ 2004: Results from the Marine Surveys of HMS Scott and the Sumatra Earthquake and Tsunami Offshore Survey (SEATOS), 2005. Geophysical Research Abstracts. 2006;8:09004

2. Zirov NF. Atlantis. M: Geografgiz. 1957. 120 p

3. Zymov SA. Resonant tide in the oceans and the problems of geodynamics. Nauka, Moscow. 1989. 120 p.

4. Cuvier J. About coups or changes on the surface of the globe in estestvoopisatelnom and historical terms. Odessa; $1840.225 \mathrm{p}$.

5. Rydoy AN. Giant current ripple (history of research, diagnosis and paleogeographic significance). Tomsk State Pedagogical University. $2005 ; 228$.

6. Ananiev GS. Catastrophic processes of relief formation. Moscow State University, Moscow; 1998. 104 p.

7. Lalomov AV. Reconstruction paleogidrodinamicheskih conditions of formation of upper Jurassic conglomerates of the Crimean peninsula. Lithology and minerals. 2007;3:298-311.

8. Rukin MD, Slavinskiy AZ, Yasmanov NA. Living pulse of the Earth. Moscow. 2003;252.

9. Zorin IV. Travel phenomenology. Part I. Ethnology travel. Sovietskiy sport, Moscow; 2004. 128 p.

10. Grosswald MG. Eurasian hydrospheric catastrophe and glaciers of the Arctic. Experience geomorphological analysis paleogidrologicheskih systems continent - Nauchhyi mir, Moscow; 1999. 118 p.

11. Danielyan Sh. Energy model of glaciers and glacial theory. Yerevan; 1999. $120 \mathrm{p}$

12. Chuvardinsky VG. About glacial theory. The origin of the glacial formations formations. Apatity, 1998. 304 p.

13. Chuvardinsky VG. Primer neotectonics. A new look at an ice age. Apatity; 2008.88 p.

14. Kalyakin VN. Natural conditions of the Late Pleistocene. In: Smirnova $\mathrm{OV}$, editor. East European forests: history in the Holocene and the present. Nauka, Moscow. 2004;59-153.

15. Kuzin IL. The extent of the validity of the theory of continental glaciations. Math RGS. 2003;135(5):51-67.

16. Lindberg GU. Large fluctuations in sea level during the Quaternary period. Nauka, Leningrad. 1972. $548 \mathrm{p}$

17. Rattsel F. Earth and life. Comparative geography. In 2 vols. St. Petersburg. 1905;1:736.

18. Odesskij IA. Rotation and evstaziya. Izv RGO. 2009;141(1):61-66.

19. Balandin RK. Secrets of the Flood. Veche, Moscow; 2003. 360 p.

20. Vernadsky VI. Selected works on the history of science. Nauka, Moscow; $1981.360 \mathrm{p}$

21. Balandin RK. Vernadsky: life, the idea of immortality. Znanie, Moscow. 1979. $176 \mathrm{p}$.

22. Stepanov IN. The theory of the relief sculpture and new thematic maps. Nauka, Moscow; 2006. 230 p.

23. Vernadsky VI. The chemical structure of the Earth's biosphere and its environment. Nauka, Moscow; 1965. 374 p.

24. Vernadsky VI. Essays on Geochemistry. Nauka, Moscow; 1983. 422 p.

25. Barenbaum AA. The mechanisms of formation of oil and gas accumulations. DAN. 2004;399(6):802-805.

26. Kauffman EJ. The structure of the extinctions of marine biota in the Cretaceous. Holocaust and the history of the Earth: New uniformitarianism (Translated from English). M: Mir. 1986;156-254. 
27. Dole C. The planet for people (translation from English.). Nauka, Moscow; 1974. 200 p.

28. Lovelock JE. Gaia: The practical science of planetary medicine. Gaia book limited. 1991. $192 \mathrm{p}$.

29. Lovelock JE. The Ages of Gaia: A biography of our living Earth. Oxford, New York, Toronto: Oxford Univ. Press; 1989. 252 p.

30. Zymov SA, Chuprynin VI. Ecosystems: stability, competition, targeted transformation. Nauka, Moscow; 1991.160 p.

31. Wrangel FP. Journey to the northern shores of Siberia and the Arctic sea committed in 1820,1821, 1822, 1823 and 1824. Expedition under the command of the fleet F.P.Vrangelya Lt. Glavsevmorput, Moscow; 1948. $456 \mathrm{p}$.

32. Nordenskiöld AE. The expedition to the mouth of the Yenisei, 1875 and 1876years. - St. Petersburg 1880. 198 p.

33. Toll EV. Fossil glaciers New Siberian islands of the mammoth carcasses ratio and period to an ice. Notes Engl geogr Islands of Society. geogr. $S P b .1897 ; 32(1): 1-139$.

34. Ides I, Brant A. Notes on the Russian Embassy in China (1692-1695) Vostochnaya Literatura, Moscow; 1967. 404 p.
35. Vereshchagin NK. The death of the mammoth fauna in the Pleistocene. Nature. 1977;9.

36. Pidoplichko IG. Paleolithic dwellings made of mammoth bones in the Ukraine. Naukova Dumka, Kiev; 1969. 164 p

37. Bronstein M, Karahan IL, Shirokov Yu. Uelen bone carvings. Folk art of Chukotka, Svyatogor, Moscow. 2002. 100 p.

38. Herder JG. Ideas for the philosophy of the history of mankind. M: Nauka, Moscow; 1977. 704 p.

39. Armand AD. «Gaia» experiment. The problem of the living Earth. Syrian Sädhana, Moscow; 2001. 192 p.

40. Taleb NN. Black Swan. Under the sign of unpredictability. Kolibri, Moscow; 2010. 528 p.

41. Ager D. The New Catastrophism: The Rare Event in Geological History. Cambridge University Press: 1995; 230 p.

42. Rydoy AN. Ice disaster in the modern history of the earth. Nature. 2000;9. 